\title{
Assessing the local perception of climate change in a small island: a case study
}

\section{José Benedicto Royuela}

Department of Geography, Universitat de les Illes Balears, Mallorca, Balearic Islands, Spain and Institut Mediterrani d'Estudis Avançats (CSIC-UIB), Mallorca, Balearic Islands, Spain Email: jose.benedictor@gmx.com *Corresponding author

\section{Sandra Hervías-Parejo}

Global Change Research Group, Institut Mediterrani d'Estudis Avançats (CSIC-UIB), Mallorca, Balearic Islands, Spain Email: shparejo@gmail.com

\section{Barbara Ambros and Azucena de la Cruz}

Sociedade Portuguesa para o Estudo das Aves,

BirdLife International, Lisbon, Portugal

Email: ambrosbarbara@gmail.com

Email: acruzmartin@gmail.com

\section{Artur Gil}

Centre for Ecology, Evolution and Environmental Changes (cE3c) and Azorean Biodiversity Group,

Faculty of Sciences and Technology, University of the Azores, 9500-321 Ponta Delgada, Portugal

Email: artur.jf.gil@uac.pt and

Research Institute for Volcanology and Risk Assessment (IVAR), University of the Azores, 9500-321 Ponta Delgada, Portugal 


\begin{abstract}
The effects of climate change are global, but small islands are among the most vulnerable places. Local populations on small islands might have a ground-based perspective of the impacts that threaten them. This study was undertaken on Corvo (Azores), where 34\% of the residents of both genders and different education levels were surveyed. Here, their understanding of climate change and their perception of its local impacts, the sense of risk, the local areas at risk, the willingness to propose mitigation and adaptation strategies, and the knowledge of regional procedures was analysed. Education played a crucial role in local understanding. The general perception was that the regional policies were insufficient to address climate change issues at the local level. This fact points out that the efforts to mitigate climate change impacts, and the public participation procedures for supporting policy-making, must be significantly increased and improved, in order to reach a real impact on local island communities.
\end{abstract}

Keywords: global change; local impacts of climate change; local perception of climate change; island-scale mitigation; adaptation policy-support; outermost European regions; OERs; overseas countries and territories.

Reference to this paper should be made as follows: Benedicto Royuela, J., Hervías-Parejo, S., Ambros, B., de la Cruz, A. and Gil, A. (2020) 'Assessing the local perception of climate change in a small island: a case study', Int. J. Global Warming, Vol. 22, No. 1, pp.30-53.

Biographical notes: José Benedicto Royuela holds a $\mathrm{PhD}$ in Human Geography in Brunel University London (UK). He has experience in the evaluation of the socio-economic impact of conservation projects: LIFE Priolo (LIFE 03 /NAT/P/000013) and LIFE Corvo (LIFE 07 NAT/P/000649) in the Azores, Portugal and LIFE Pinzón Azul (LIFE14 NAT/ES/000077) in Canarias, Spain. In his $\mathrm{PhD}$, he studied in depth the keystone elements required in sustainable small communities living in isolated territories (relation to natural capital, challenges of development in a reduced territory, potential negative impacts of human activity...). He is the author of nine papers in relevant journals.

Sandra Hervías-Parejo is a Postdoctoral Researcher at the Mediterranean Institute for Advanced Studies (IMEDEA, UIB-CSIC), in Spain. She completed her $\mathrm{PhD}$ on tropic networks and the impact of invasive alien species on the Biodiversity of Corvo (Azores Islands), and since then has been working on projects covering several archipelagos, namely, the Canary, Madeira, Balearic and Galápagos. Her main research interest focuses on important ecosystemic functions, in particular seed dispersion and pollination, and the use of complex networks to evaluate the causes and consequences of global changes. She is already the author of 20 papers in SCI journals, and has been a lecturer on the Master of Wild Fauna Management of Murcia University since 2011.

Barbara Ambros is a Biologist by the Universitat Autònoma de Barcelona. She holds an MSc in Management and Conservation of Biodiversity by the Universitat de Barcelona. Currently, she is finishing an MSc in Environment Law by the Universitat Rovira i Virgili. Natural from Barcelona, now lives in Azores, Portugal, where have been work in a seabird conservation program with the Portuguese Society for the Study of Birds|BirdLife International Portugal. Nowadays, she works in the Wild Birds Interpretation Center in the small island of Corvo. 
Azucena de la Cruz holds a degree in Environmental Sciences from Rey Juan Carlos University in Madrid, with a specialisation in nature conservation and management and another in environmental citizenship. She has worked for SPEA - BirdLife partner in Portugal since 2006. Initially, as an intern in the LIFE Priolo project, where she studied the Socioeconomic Benefits of Special Protection Area Pico da Vara/Ribeira do Guilherme. She coordinated the Priolo Environmental Center since its opening in 2007, and led the Lands of Priolo's application to the European Charter for Sustainable Tourism since 2011. She is currently Joint Head of SPEA Azores, where she focuses on marine conservation and citizenship.

Artur Gil is a Biophysical Engineer and holds an MSc in Spatial Planning and a $\mathrm{PhD}$ in Environmental Sciences. He is currently a Researcher in Geospatial Sciences and Technologies-based at the University of the Azores, in Portugal. His current research is focused on the development of geospatial applications, products, and indicators able to support decision-making on spatial planning, climate change mitigation/adaptation, nature conservation, coastal/land management, and natural hazards assessment in islands. He has already published more than 40 papers in SCI-indexed peer-reviewed scientific journals with about 200 scientists from many different countries and with diverse scientific backgrounds.

\section{Introduction}

There is little doubt that ongoing climate change is directly or indirectly caused by human activity (National Research Council, 2011; Weir and Pittock, 2017; IPCC, 2018). The European Commission has led efforts, since the beginning of the 21 st century, to reduce its greenhouse gas emissions by $40 \%$ from 1990 levels by the year 2050, thus meeting the Kyoto Protocol targets (UNCFCC, 1997). However, the global effects of climate change (e.g., melting ice sheets and glaciers, erosion of coastal areas due to rising sea-level), mostly as a result of greenhouse gas production from burning fossil fuels, deforestation, and agricultural activity, have not been reduced. It is even expected that the negative consequences of climate change will be worsening in the future (IPCC, 2018).

Small islands are considered to be at the forefront of these impacts, although islands' inhabitants are not, in the main, responsible for the majority of global climate change emissions. This vulnerability is mainly due to the influence of the surrounding sea, which increases the frequency and strength of extreme weather hazards and the impact of sea-level rise. For example, Small Island Developing States are predicted to be among the most vulnerable countries (Nurse et al., 2014; Weir and Pittock, 2017; IPCC, 2018).

Sustainability on small islands has also been compromised by inappropriate planning, development, and management of these small territories, for instance, land use/land cover planning and management [see Fernandes et al. (2015), Gil (2016) and Gil et al. (2018) for some case studies]. Such factors influence the predicted consequences and should be taken into account when defining strategies to mitigate most of the climate change's negative impacts. Although the impacts are exogenous, adaptation strategies can be locally planned by promoting the resilience of communities.

We focused on a European small oceanic island to understand the perception of local communities on how climate change impacts on the territory. The main aims of this study were to: 
1 have an initial idea on how island inhabitants perceive the potential impacts of climate change in their island

2 assess whether residents' perceptions on the local impact of climate change are aligned or not with official planning, and whether locals can effectively contribute to defining adaptation strategies to reduce local climate change impacts.

Specifically, we pursued five objectives:

1 to have a perception of the understanding of residents on climate change

2 to evaluate their sense (or not) of associated risks (i.e., droughts, sea-level rise, impact on local fisheries, increase of tropical diseases and threats to local flora and fauna)

3 to identify potential threatened areas

4 to evaluate their willingness to propose mitigation and adaptation solutions to overcome climate change challenges

5 to assess their knowledge of regional strategies related to climate change.

\section{Adaptation strategies to climate change impacts in small islands: the cases of outermost European regions, overseas countries and territories, and small islands development states}

Outermost European regions (OERs) are the primary reference for this research, but results can be relevant for overseas countries and territories (OCTs). OCTs depend constitutionally on three of the EU member states (Denmark, France, and the Netherlands), they share similar characteristics to OERs, but with a higher level of autonomy as they are not directly subject to EU law and they do not form part officially of the EU territory. Still, they benefit from the 'associate' status given to them by the Lisbon Treaty. Historical and geographic reasons mostly explain the differences between OERs and OCTs. It has been reported that the risks related to climate change impacts on the OCTs are high for energy security, biodiversity, and a tourism-based economy (Fernández and Cejas, 2009).

Due to their situation and their political weight, the Small Island Development States (SIDS) have been the subject of many studies and, therefore, they provide a wealth of knowledge relevant to other islands. SIDS are particularly sensitive to climate change, and natural disasters and are also exposed to persistent vulnerabilities related to intermittent water and energy supply, emigration flows, low self-sufficiency and difficulties to preserve the local heritage (Briguglio, 1995; Pelling and Uitto, 2001; Kelman and Lewis, 2005; Kelman and West, 2009; Kelman, 2010). Island territories have not always been managed in a sustainable way (Gil et al., 2018). Moreover, it is unclear whether most islanders are unaware of ongoing climate change (Betzold, 2015) or that climate change is not their primary concern (McNaught et al., 2014). For example, there is a strong record of community resilience to environmental variability in Pacific islands, explained either by substantial social capital or by the importance of traditional knowledge (Nunn et al., 2017; Weir et al., 2017). 
OERs share several geographic similarities and proximity to SIDS and benefit from a particular political status within the European Union (Gil et al., 2012). Due to the support of the States and the European institutions, OERs are privileged areas in which to undertake demonstration projects that can be of high relevance for other small islands. The OERs are listed in Article 349 of the Treaty on the Functioning of the European Union. It is worth noting that OERs - except French Guiana - are small islands or archipelagos. In 2006, almost 4.3 million people lived in OERs, representing $0.9 \%$ of the European Union population. European Commission communication COM(2008)/642, entitled 'The outermost regions: an asset for Europe', advocates for an approach focusing on the potential contribution of these regions to overall growth and development in Europe, by adopting as a strategic priority the turning of handicaps (remoteness, insularity, terrain and climate constraints, economic dependence and a narrow range of locally produced goods) into assets. There is a lack of studies on their understanding of OERs' socio-ecological systems of climate change impacts (Banos-González et al., 2015, 2016). As most of the OERs are small remote islands, their geographical and geological characteristics give them the unique geostrategic position to be small scale models for research in several fields including climate change (see for instance, how the Smart Islands Initiative of European islands emphasises on islands as laboratories for innovation).

Climate change adaptation requires considering local perceptions of the potential effects of climate change and local proposals for contingency strategies, for instance, taking advantage of traditional ecological knowledge (Alexander et al., 2011). Considering local suggestions and perceptions of climate change might also increase the sense of ownership of potential policies that could be informed by the research process. Small communities can design 'self-development strategies' that can support local economic success (Korsching and Allen, 2004); it is reasonable to think that it also applies to climate change adaptations. Territorial planning on small islands is challenging because strategies for land/coastal/marine management must consider many (often conflicting) criteria, such as biodiversity conservation, socio-economic development, sustainability, isolation, and seasonality. For instance, there is a developing challenge associated with the location of human settlements. This issue is crucial on small islands where the territory is a scarce resource, and alternatives for local resettlement are generally restricted. Attachment to place and a higher sense of ownership that islanders have towards their islands also play a role in the perception of risk (Mortreux and Barnett, 2009).

Grydehøj and Kelman (2017) propose that small islands should focus on local solutions for development and adaptation strategies for climate change impacts rather than falling into the trap of becoming examples of sustainability. This is linked to the potential of small islands as iconic places for tourism as they can become touristic examples of sustainability. However, this goal might risk discouraging islanders from undertaking specific solutions to limit local impacts of climate change (for instance, the construction of artificial coastal barriers to protect the inhabited areas under threat). A substantial social capital, with the implication of knowledge transfer, is also a source of resilience. Resilient society is more able to learn and adapt to change, namely regarding climate change (Adger et al., 2005; Baldwin and Chandler, 2010). In general, confidence in the government is a precondition for effective public participation in policymaking. But fostering citizenship when there is not sufficient confidence in the government does not seem to be efficient (Stewart, 1995). Therefore, it is essential to assess the level of 
knowledge that local populations show towards sectoral and multi sectoral policies, as it might indicate the type of relationship that locals have with decision-makers.

\section{The Azores: context and climate change strategy}

In the Azores Autonomous Region (with a regional government and parliament that lead decision-making and that can legislate at regional level), the first concrete policy effort to foster sustainable development was made in November 2004 with the publication of the 'Sustainability Perspectives in the Azores Autonomous Region' (SRAM, 2004). Although indirectly, this document was the first implicit climate change mitigation strategy in multi-sectoral policies. Nevertheless, it had little success and no material impact on multi-sectoral public policies. In 2009, the Azorean Regional Government officially declared climate change as one of the main threats to the sustainable development of the archipelago with the creation of a 'Regional Commission on Climate Change in the Azores' (ComClima). It was founded by a restricted and selected board of scientists, major multi-sectoral public/private stakeholders, and policy-makers. ComClima was endorsed by the Regional Government to develop the 'Regional Strategy for Climate Change' (ERAC in its Portuguese acronym). The ERAC (Government Council 123/2011 of October 9th, 2011) aimed at addressing both mitigation and adaptation issues in the Azores. The 'Regional Plan for Climate Change' (PRAC), developed through a participative process with contributions from the population and stakeholders, will operationalise the ERAC. PRAC development started in 2014 (Regional Government Council Resolution 93/2014, of May 28th, 2014) with the support of a broad group of scientists, technical experts, policy-makers, and most relevant regional public and private companies and NGOs. It constitutes an essential, transversal, and multi-sectoral decision-support tool for public policies affecting or potentially being affected by climate change. Operationally speaking, PRAC aims primarily at quantifying and reducing the regional greenhouse gases emission, and therefore:

1 decreases the vulnerability and exposure to climate risks

2 increases the resilience to extreme meteorological events

3 improves the capacity of response in case of emergencies.

PRAC was subject to an open and public consultation process undertaken at a Regional level between October 13th and November 15th of 2017 (PRAC, 2017) and was approved and ratified by the Azorean Regional Parliament in late 2018, being finally published in the Regional Decree-Law 30/2019/A of November 28th.

In the Azorean Region, there is a lack of studies analysing local perceptions of climate change effects. The only similar inquiry was undertaken on São Miguel (eastern group), the most populated and developed Azorean island, where the surveyed population was found to have a reasonably good understanding of climate change and its threats (Cunha et al., 2010). Corvo's small size $\left(17 \mathrm{~km}^{2}\right)$ and apparent geographic simplicity offered the opportunity to assess the understanding the surveyed population had on these issues and related challenges, assuming that they had a reasonably good knowledge of the territory. Corvo's characteristics provide the opportunity to understand the situation of other OERs, mainly the Macaronesian Islands (the Azores, Madeira, and the Canary Islands), at a smaller scale. 


\section{Study area}

Corvo is the smallest, most northern, remote, and least populated island in the Azores Archipelago [437 inhabitants, according to INE (2011)] - see Figure 1. This mostly mountainous island (the only flat area is the southern point) culminates at $721 \mathrm{~m}$ of altitude in the Morro dos Homens summit. Natural vegetation covers $51 \%$ of its territory. Of the remaining land, $32 \%$ is pastures, $7 \%$ agriculture land, $2 \%$ forest, and only $1 \%$ is an inhabited area. The Caldeirão dominates the centre of the island and is the most important geomorphologic feature of Corvo, a subsidence caldera with about $2 \mathrm{~km}$ in diameter and $300 \mathrm{~m}$ in depth, containing a lake. The south of the island is the only flat area; there can be found the main infrastructures and habitations.

Figure 1 Corvo Island (see online version for colours)

\section{Land uses}

Natural vegetation area

Forest area

Urban area

Livestock area

Agricultural area
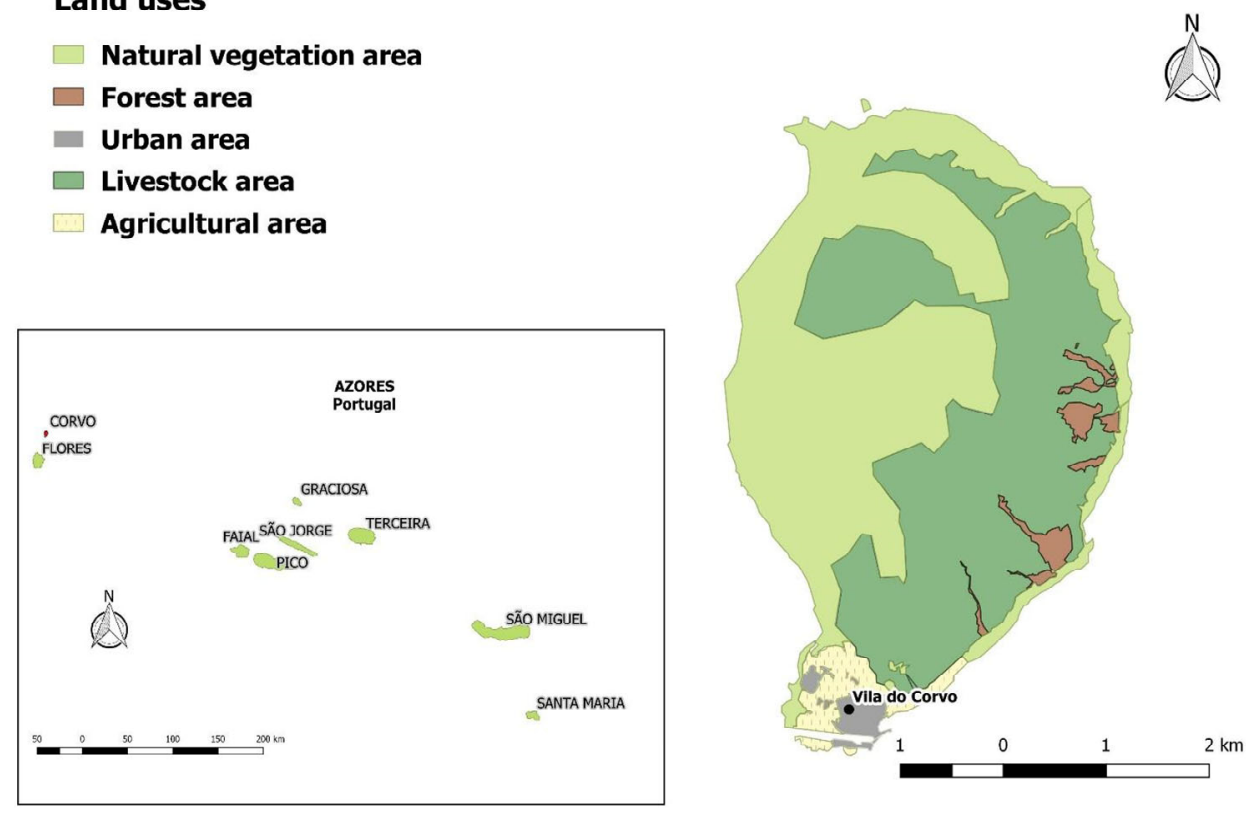

Source: Own elaboration

The population is concentrated in the unique inhabited area of the island, Vila do Corvo. Residents between $25-64$ years represent $61.4 \%$ of the total population. The second most representative age group is over 65 years $(16.5 \%)$, followed by those between $0-14$ (14.2\%) and the 15-24 years old (7.9\%) (INE, 2011). On the island, 76\%, 13\%, and 7\% of the population have, respectively, primary, secondary, and tertiary education. The main infrastructures of the island, port, and airport, are close to the inhabited area. The southern area, where Vila do Corvo is located, also hosts croplands whose products are locally consumed. The service sector provides the main economic activity, although farming is also a source of revenue. Corvo is entirely dependent on fossil fuel for its energy. According to PRAC (2017), flooding is the leading climate change-related risk, especially in the urban area. The latest extreme weather-related event happened in 
October 2012 when a landslide on the north-western coast of Corvo was induced by high precipitation and strong wind (Melo et al., 2018).

\section{Methodology: population survey}

Between December 4th of 2017 and January 23th of 2018, a survey was conducted among the resident population using a standardised questionnaire with 19 closed and 13 open questions (see the Supplementary material). The surveyed residents were contacted directly at their homes or in the streets. Questionnaire participants $(n=148)$ were selected to obtain a sample representative of the residents of the Island. However, individuals with higher educational levels were more willing to participate in the inquiry. Almost $34 \%$ of the total residents on Corvo (437 in 2011) were surveyed; 73 women and 75 men aged from 15 to 85 years (the sample is, therefore, representative of the total resident population). The following socio-demographic data were recorded:

1 origin (Corvo, another island or mainland)

2 educational level (preliminary, secondary or university)

3 age group (see Table 1)

4 gender

5 profession (see Table 1)

6 whether the survey participant was a member of any environmental association.

The questions concerning climate change aimed to answer the four main research questions depicted in Figure 2 and were:

$7 \quad$ What is climate change?

$8 \quad$ Does it really exist?

$9 \quad$ What its main cause is?

10 Can anything be done to prevent it?

11 What are the current local effects?

12 Will climate change impact negatively on humans, biodiversity, or both?

13 How will local effects be in the near future?

14 Will climate change bring any benefit to Corvo?

15-20 Will rain and wind rise/drought/sea-level rise/fishery impact/tropical diseases/threats on flora and fauna be a risk for the Corvo population?

21 Is the regional government taking action against it?

22 What the PRAC is?

23 Should the regional government take into account local knowledge and suggestions to help fight climate change?

24 What can be done individually to reduce climate change? 
25 What can be done collectively to mitigate the effects?

26 Which places are identified as being most vulnerable?

To start the inquiry, interviewees were asked about their understanding of climate change. About $10 \%$ of the participants $(n=15)$, a minority in the sample, declared that they did not know what climate change is. A short but objective explanation (Box 1) was given to them to help them reflect on its local risks and impacts.

Figure 2 The main research questions covered by this study and the steps taken to find out the answers

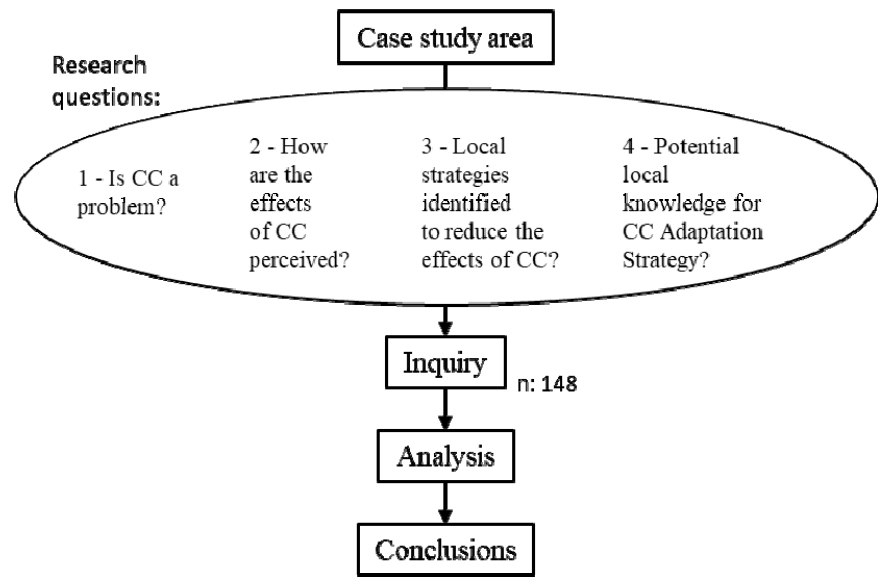

Notes: The main research questions covered by this study and the steps taken to find out the answers. CC meaning here climate change.

Box 1 Information on climate change given to the survey participants who had no previous knowledge of this matter

In the last 100 years, the global temperature of the planet has increased by about $0.85^{\circ} \mathrm{C}$.

Scientists relate this rise in temperature to the emission of greenhouse gases, such as carbon dioxide, methane, and nitrous oxide, which come mainly from fossil fuels (gasoline, diesel, fuel, coal, etc.) but are also associated with livestock (cows and sheep) and deforestation.

Predictions point to a continuous increase in the global temperature. It is considered that a rise of $2^{\circ} \mathrm{C}$ in relation to the temperature of the pre-industrial era could have dangerous and possibly catastrophic consequences, namely:

- periods of very heavy rain and wind

- increased droughts

- melting of polar ice caps

- sea-level rise

- increase of coastal erosion

- changes in the marine currents and temperature of marine waters, which can affect fisheries

- displacement of tropical diseases to places where they were not present

- disappearance or displacement of species of flora and fauna. 


\section{Statistical analysis}

To use the causes associated with climate change as a quantitative variable, responses were coded numerically from 1 to 3 :

1 humans

2 environment

3 both humans and the environment.

The effects of climate change on Corvo were coded as:

1 main problem

2 significant problem

3 secondary problem

4 no problem.

The opinion of the participants about whether the Azorean Regional Government is taking sufficient action to reduce climate change and its impacts as:

1 yes

2 no

3 yes, but it is not enough.

Firstly, researchers assessed the leading causes associated with climate change, the perceived impacts of climate change, whether the regional government is acting against climate change, and finally, if the interviewees had prior knowledge of the PRAC. This was done by including each as a dependent variable in separate generalised linear models, with the library 'stats' (glm function) and the library 'multcomp' (glht function) in R 3.4.3 (R Core Team, 2017). Origin, age range, gender, level of education, the profession of participants, and membership (or not) of an environmental association were included as explanatory variables to test their influence on participants' answers. This analysis allows the investigation of the possible effect of several traits of the residents on their responses.

To evaluate if the interviewees considered that local climate change impacts will increase in the near future, differences between current and future effects were tested by a crosstab with chi-square analysis and Bonferroni post hoc tests (library 'fifer', chisq.test and chisq.post.hoc functions). Lastly, spearman correlations (library 'Hmisc', rcorr function) were used to evaluate if participants with prior knowledge of the PRAC were more able to identify climate change causes and main impacts.

All analyses performed are commonly used in questionnaire surveys to properly test this type of interviewing data (Taherdoost, 2016; Razzak and Heumann, 2020). 


\section{Results}

The majority of the people surveyed (55\%) were originally from Corvo, $27 \%$ came from another Azorean island, and 2\% from São Tomé and Principe and Cape Verde (African small oceanic island states). Finally, $16 \%$ of the interviewees were from continental areas (mainland Portugal, Angola, France, and the USA). Almost half of the participants (51\%) had only an elementary education level. The most common occupations were services $(39 \%)$ and education (13\%) (Table 1$)$.

Table 1 Quantitative description of participants according to their age range, education level, and profession

\begin{tabular}{|c|c|}
\hline Age (years) & $n$ participants \\
\hline$<20$ & 10 \\
\hline $20-29$ & 22 \\
\hline $30-39$ & 38 \\
\hline $40-49$ & 40 \\
\hline $50-59$ & 16 \\
\hline $60-69$ & 15 \\
\hline$>70$ & 7 \\
\hline \multicolumn{2}{|l|}{ Education level } \\
\hline Preliminary school & 76 \\
\hline Secondary school & 45 \\
\hline University & 27 \\
\hline \multicolumn{2}{|l|}{ Profession } \\
\hline Agriculture and agroindustry & 11 \\
\hline Civil servant & 6 \\
\hline Construction & 8 \\
\hline Homemaker & 11 \\
\hline Education & 20 \\
\hline Entrepreneur & 5 \\
\hline Environment & 3 \\
\hline Fishery & 5 \\
\hline Policy-maker & 3 \\
\hline Retired & 7 \\
\hline Services and sales & 58 \\
\hline Student & 11 \\
\hline
\end{tabular}




\section{Climate change and its impact on Corvo}

Overall, for $97 \%$ of participants, climate change is occurring. From these, only $26 \%$ associated climate change with global warming, and 57\% defined it as an alteration of the seasons and extreme weather conditions, but without mentioning global warming. The $10 \%$ who could not explain climate change were mainly composed of people with only preliminary school level education and aged over 40 years old. The majority of the surveyed $(76 \%)$ believed that human activity was the leading cause of climate change. Women aged from 20 to 39 years and with university degrees recognised human-induced climate change more than any other group $\left(F_{5}=14.4 ; p<0.001\right)$.

The respondents acknowledged climate change as a problem for Corvo. However, there were differences in the opinions about the effects of climate change in the present moment vs. the near future $\left(X^{2}=36.7, p<0.001\right)$. About $46 \%$ of the respondents thought that the current effect was considered as a secondary problem, while $70 \%$ thought that it will be an important problem in the near future. Participants' origin (from Corvo, another island or mainland) seems to influence how they see both current and future effects of climate change $\left(F_{3}=628.9 ; p<0.001 ; F_{3}=628.9 ; p<0.001\right.$, respectively $)$. In an open question, the Caldeirão and Vila do Corvo were by far the most vulnerable areas to climate change impacts identified in the inquiry (Table 2 and Figure 3 ).

Table 2 Most vulnerable areas of Corvo for climate change impacts identified by the interviewees (see online version for colours)

\begin{tabular}{lc}
\hline Most vulnerable areas & \% interviewees $\left(n=146^{*}\right)$ \\
\hline Vila do Corvo & 36.3 \\
Port & 2.7 \\
Beach & 2.1 \\
\hline Total human settlement and infrastructures & 41.1 \\
\hline Caldeirão & 39.7 \\
Baldio & 2.1 \\
Miradouro & 1.4 \\
Morro dos Homens & 0.7 \\
\hline Total interior of the island & 43.8 \\
\hline Northwest coast & 8.2 \\
Pão de Açúcar & 2.1 \\
Ponta do Marco & 1.4 \\
South coast & 1.4 \\
Coroa do Pico & 0.7 \\
Espigãozinho & 0.7 \\
\hline Total coastal area & 14.4 \\
\hline The whole island & 0.7 \\
\hline
\end{tabular}

Note: *Two participants did not identify any vulnerable area. 
Figure 3 Areas identified as most vulnerable to climate change effects on the island of Corvo (see online version for colours)

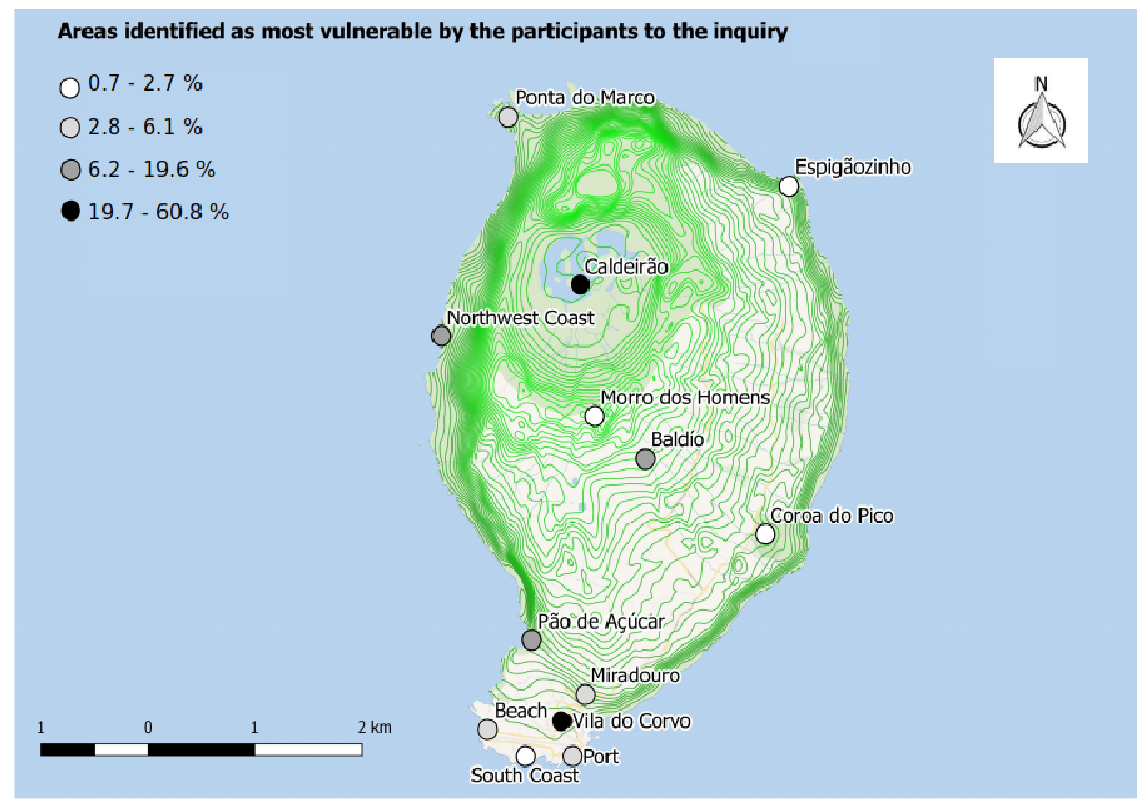

Source: Own elaboration

Table 3 Percentage of interviewees considering the risk of six potential impacts of climate change on Corvo (see online version for colours)

\begin{tabular}{lcc}
\hline Potential impacts & There is no risk & There is a risk \\
\hline Rain and wind rise & $8.1 \%$ & $91.9 \%$ \\
Droughts & $2.7 \%$ & $97.3 \%$ \\
Sea-level rise* & $27.7 \%$ & $71.6 \%$ \\
Fishery impact & $3.4 \%$ & $96.6 \%$ \\
Tropical diseases & $11.5 \%$ & $88.5 \%$ \\
Threats to flora and fauna & $27.0 \%$ & $73.0 \%$ \\
\hline
\end{tabular}

Note: *Regarding the 'sea-level rise' impact, one participant answered, 'I do not know if there is a risk or not'.

The interviewees were asked whether climate change was likely to have potentially adverse impacts (previously identified in Table 3) on Corvo. Rain and wind increase, droughts, and fishery impact were foreseen by more than $90 \%$ of the respondents (Table 4). 
Table 4 Main solutions proposed by the interviewees to mitigate the potential impacts of climate change on Corvo

\begin{tabular}{|c|c|c|}
\hline Potential impacts & $\%$ interviewees $(n=148)$ & Main solutions \\
\hline \multirow[t]{3}{*}{ Rain and wind rise } & 91.9 & Do not know $17.6 \%$ \\
\hline & & Nothing can be done $33.1 \%$ \\
\hline & & Cleaning up actions $12.5 \%$ \\
\hline \multirow[t]{3}{*}{ Droughts } & 97.3 & Do not know $22.9 \%$ \\
\hline & & Store clean drinking water $18.7 \%$ \\
\hline & & Reduce water consumption $16.0 \%$ \\
\hline \multirow[t]{3}{*}{ Sea-level rise } & 71.6 & Do not know $32.0 \%$ \\
\hline & & Nothing can be done $24.5 \%$ \\
\hline & & Protect coastal areas $20.7 \%$ \\
\hline \multirow[t]{3}{*}{ Fishery impact } & 96.6 & Do not know $39.9 \%$ \\
\hline & & Nothing can be done $30.8 \%$ \\
\hline & & Reduce pollution $5.6 \%$ \\
\hline \multirow[t]{3}{*}{ Tropical diseases } & 88.5 & Do not know $23.7 \%$ \\
\hline & & Vaccination and prevention $36.7 \%$ \\
\hline & & Quarantine 7.6\% \\
\hline \multirow{3}{*}{$\begin{array}{l}\text { Threats to flora and } \\
\text { fauna }\end{array}$} & 73.0 & Do not know $30.5 \%$ \\
\hline & & Species conservation $16.7 \%$ \\
\hline & & Reforestation $12.0 \%$ \\
\hline
\end{tabular}

\section{Local mitigation strategies against climate change and the perception of regional initiatives}

To reduce climate change, more than $67 \%$ of the participants argued that something can be done (Table 5). Recycling, implementing alternative (renewable) energy systems, and reducing pollution were the individual actions most frequently suggested by the interviewees while improving collaboration between locals was the most popular collective action.

Some mitigation strategies proposed by the research participants relate to those included in the PRAC: implementation and use of renewable/alternative energies, promoting recycling, decreasing energy consumption, awareness campaigns, and reducing pollution (although the PRAC directly refers to greenhouse gas emissions). Interestingly, despite the initiatives considered by the Azorean Regional Government (and previously described) and those proposed by residents being related, 79\% of them did not know the PRAC. Furthermore, 55\% of the interviewees thought that the government is not taking action against climate change. Retired residents and those working in services knew better the PRAC $\left(F_{1}=4.1 ; p<0.001\right)$. Neither the main causes nor the effects of climate change correlated with knowledge about the PRAC $\left(r_{s}=-0.01\right.$, $p=0.898 ; r_{s}=-0.08, p=0.324$, respectively). 
Table 5 Main individual and collective actions to reduce climate change proposed by the interviewees in an open question

\begin{tabular}{|c|c|c|c|c|}
\hline & $\begin{array}{l}\text { Nothing can } \\
\text { be done }\end{array}$ & $\begin{array}{l}\text { Do not know } \\
\text { or no reply }\end{array}$ & $\begin{array}{l}\text { Something } \\
\text { can be done }\end{array}$ & Actions \\
\hline \multirow[t]{5}{*}{$\begin{array}{l}\text { Individual } \\
\text { actions }\end{array}$} & $0.7 \%$ & $31.7 \%$ & $67.6 \%$ & $\begin{array}{l}\text { Recycling and implementing } \\
\text { alternative energies } 40.0 \%\end{array}$ \\
\hline & & & & Reducing pollution $34.4 \%$ \\
\hline & & & & $\begin{array}{l}\text { Reducing water consumption } \\
12.0 \%\end{array}$ \\
\hline & & & & $\begin{array}{l}\text { Habitat and species conservation } \\
4.0 \%\end{array}$ \\
\hline & & & & $\begin{array}{l}\text { Reducing energy consumption } \\
3.0 \%\end{array}$ \\
\hline \multirow{5}{*}{$\begin{array}{l}\text { Collective } \\
\text { actions }\end{array}$} & $5.4 \%$ & $17.6 \%$ & $77.0 \%$ & Improving collaboration $27.2 \%$ \\
\hline & & & & Reducing pollution $21.0 \%$ \\
\hline & & & & $\begin{array}{l}\text { Recycling and implementing } \\
\text { alternative energies } 19.3 \%\end{array}$ \\
\hline & & & & Awareness campaigns $12.3 \%$ \\
\hline & & & & $\begin{array}{l}\text { Reducing water consumption } \\
7.9 \%\end{array}$ \\
\hline
\end{tabular}

\section{Discussion}

The overall results of this study are mainly considered 'island-specific' (Kubo et al., 2018; Perkins and Krause, 2018), as their specificity is mostly centred in the 'islander' perception of his/her island's territory. The analysis of the data points out the relevance of gender, age, and education in the understanding of climate change causes. Findings support the idea that women are usually more informed about climate change issues (McCright, 2010). Younger individuals might have more access to knowledge than their elders as nowadays the emphasis is generally put into environmental issues in primary and secondary education; therefore, they tend to be more informed about these subjects (Poortinga et al., 2011). Data show that the population group that should be targeted as a priority by awareness-raising and educational actions on climate change issues is men above 40 years old.

Origin influenced how islanders see the effects of climate change. People from Corvo, who could be expected to be more familiar with the island and thus its vulnerabilities, were more aware of the dangers of climate change compared to those from other islands or continents. The higher perception of risk among natives might be explained by their higher sense of ownership, supporting Mortreux and Barnett's (2009) hypothesis. The higher awareness of this population group is essential to consider in local and regional decision-making processes. This is especially relevant in an archipelagic and dispersed region such as the Azores.

In what concerns the identification of most vulnerable areas, Vila do Corvo (considered the second most susceptible place on the island) is where the population lives, thereby pointing towards an anthropocentric sense of danger. The only human 
settlement is, in fact, located in an area close to the coast and overhung by cliffs. The vulnerability of the Caldeirão can be explained by the fact that it is the most iconic natural area of the island and the most attractive for tourists, and, also, because it has already been threatened by landslides (Melo et al., 2018).

For the main risks' assessment on Corvo, residents may be concerned about the potential risk of an increase in winds and rains because they represent some of the most historically threatening events (the weather on the Island is windy and humid, with $915.7 \mathrm{~mm}$ of annual precipitation). Residents also showed concern about droughts. Corvo lacks natural freshwater sources, and it is only since the two artificial water ponds were built at the beginning of the 21 st century that the population has benefited from the regular provisioning of water. Thus, although the island is characterised by its humidity and rainy climate, droughts can put stress on water management. Finally, because fishing is one of the few local activities that sustain the self-sufficiency of the island, it seems reasonable that residents are preoccupied with potential reductions of fish stocks. Studies undertaken in the Canary Islands have identified the introduction of tropical fish species in the archipelago (Brito et al., 2005) and the reduction of algae due to climate change (Martínez et al., 2015).

The risks assessed in the present research could affect other islands; therefore, this knowledge can be helpful to other islands. So far, few studies of this kind have been undertaken in the OERs. Hernández-González et al. (2016) assessed the effects of climate change events, among other hazards in the Canary Islands: heatwaves, air pollution, and atmospheric dust coming from the Saharan desert; these differ from those identified in the present study, but in the future, they may impact the island. Therefore, although each region or Island could undertake similar studies, although each region or island could undertake similar studies, their outcomes can help enlightening other cases.

Despite acknowledging the potential impacts associated with climate change, most of the respondents felt that nothing could be done, or they ignore the mitigation solution(s). Two main ideas arise from this: the population feels powerlessness in the face of the impacts of climate change (which have not been provoked locally), and that there are no easy solutions to avoid/mitigate climate change. However, there were numerous individual and collective actions proposed to reduce the impact of climate change on the island. These solutions varied following the risks, namely mitigation solutions (reducing water consumption to fight droughts, reducing pollution, species conservation, and reforestation), risks prevention and adaptation (clean up actions of water beds to prevent floods, protect coastal areas, and vaccination, prevention, and quarantine for potential tropical diseases). This shows the potential of the local population to propose ideas to address these challenges.

Regarding the residents' knowledge of the PRAC and the coherence of their contributions to it, there are essential aspects to be commented on. On the one hand, the inquiry was the opportunity to identify the hierarchy of the threats as perceived by the residents. They place increases in rain and wind (with the associated floods) and droughts as principal threats (Table 3), whereas sea-level rise was the leading risk identified by the PRAC. The feeling that sea-level rise was not the main risk for the respondents can be explained by the false sense of security produced by the high cliffs that are dominant on Corvo Island. But, due to the volcanic origin of the island, the basaltic rocks that compose it are prone to erosion, making the coastal areas and cliffs especially vulnerable.

On the other hand, although the perception of threats is different, and residents do not have an in-depth knowledge of regional initiatives in that matter, both the local 
population and the Regional Government identify Vila do Corvo as one of the most vulnerable areas. The PRAC states that Vila do Corvo could be directly affected by floods as it sits downstream of a dangerous area for floods (above $35 \mathrm{~m}$ above sea-level). From that perspective, it seems that there are grounds for consensus, and the population might easily accept contingency interventions in this area. However, further efforts in informing the community and explaining the logic behind the potential interventions should be made.

\section{Conclusions}

The present research project was the opportunity to identify the main lines of the perceptions of climate change impacts across a whole island from its small local community. Most Corvo residents acknowledged the existence of climate change and believed that human activities were their primary cause. However, sociodemographic factors such as education, gender, and age appear to influence the perceptions on these issues; awareness-raising actions should be targeted to be more efficient. Even though the current effects of climate change on the island are still not noticeable, most residents (and, in particular, people originally from Corvo) were confident that its consequences would worsen. Although most participants of the survey agreed that there could be individual and collective actions undertaken to mitigate the effects of climate change, they showed difficulties when asked to propose suitable solutions.

Sea-level rise and floods were not seen as a primary concern, nor as a general impact, nor as a main threat to specific coastal areas, whereas they were identified as the main risks by the 'Regional Plan for Climate Change' (PRAC, 2017). The coastal vulnerability index (a measure of the exposure to hazards that affect the coastline) is medium along most of the coast, which is dominated by steep cliffs ( $>200 \mathrm{~m}$ in height) (PRAC, 2017). This divergence can be explained by the differences between the perception of risk (which is typically derived from a lived experience) and the assessed risk (which is usually derived from technical measurements, etc.).

The general perception was that the regional government was not undertaking enough and effective initiatives to address climate change challenges, although there was little knowledge of the regional plan. The deficient dissemination of the content of regional policies and programs among the general public and the differences in how lay citizens formulate their perception pointed-out at the need that decision-makers should put further efforts to listen to the local population to better incorporate their contributions into plans. This last point is not exclusive of the ideas that new efforts can be made to inform the community (impartially and with sound scientific evidence) and to improve the relationship with locals. Indeed, it was observed that there was, although implicitly, a common concern about the urban area's vulnerability, therefore indicating a basis for an increased population - decision-maker's mutual understanding. The decision-making process would benefit by having a local society that is aware of the existing challenges, and by understanding the population's level of knowledge of these issues.

Further efforts need to be made by the regional government to disclose mitigation and adaptation strategies to reduce climate change and to tackle its local challenges. Local action plans should include information sharing on climate change, and awareness-raising to increase support for future initiatives. Otherwise, such efforts could be ignored or rejected by the local population. These might include: rehousing, coastal protection, 
reduction in electricity and water consumption, decrease in pollution, and use of alternative energy sources. This study provides some insights into the local population's expectations, their degree of concern, and their willingness to be active in the process. This is crucial in decision-making processes because expectations and levels of concern play a vital role in the design and implementation of successful strategies to address challenges inherent to local and global climate change impacts. This applies to other places where decision-making can benefit from local knowledge and trustworthy, informed inhabitants. As OERs are mostly islands that are neighbouring OCTs and SIDS (in the Caribbean: Martinique, Guadeloupe, Saint-Martin; in the Macaronesia: Canary Islands, Madeira, and the Azores; and in the Indian Ocean: La Réunion and Mayotte), they must share information and collaborate regionally to develop adapted solutions.

\section{Acknowledgements}

We would like to thank Andreia Silva for her help with the inquiries, all the participants to the research and all the Corvo inhabitants that cherish and preserve the local environment: Tânia Pipa, Pedro Domingues, his nephew Rui, and so many others. We would also like to thank the referees and the editor of the journal for their contributions and the support for the present article. The co-author José Benedicto Royuela would like to thank Professor Susan Buckingham, Juan Guilloto and Darci Rush for their support. The participation of co-author José Benedicto in this study was undertaken under Overtourism in Spanish Coastal Destinations, Tourism Degrowth Strategies (RTI2018094844-B-C31) project and, at the beginning, under the IPI2017010110 grant from the ‘Agencia Canaria de Investigación, Innovación y Sociedad de la Información' (ACIISI).

\section{References}

Adger, W.N., Arnell, N.W. and Tompkins, E.L. (2005) 'Successful adaptation to climate change across scales', Global Environmental Change, Vol. 15, No. 2, pp.77-86.

Alexander, C., Bynum, N., Johnson, E., King, U., Mustonen, T., Neofotis, P., Oettlé, N. et al. (2011) 'Linking indigenous and scientific knowledge of climate change', BioScience, Vol. 61, No. 6, pp.477-484.

Baldwin, C. and Chandler, L. (2010) 'At the water's edge': community voices on climate change', Local Environment, Vol. 15, No. 7, pp.637-649.

Banos-González, I., Martínez-Fernández, J. and Esteve, M.Á. (2016) 'Tools for sustainability assessment in island socio-ecological systems: an application to the Canary Islands', Island Studies Journal, Vol. 11, No. 1, pp.9-34.

Banos-González, I., Martínez-Fernández, J. and Esteve-Selma, M.A. (2015) 'Dynamic integration of sustainability indicators in insular socio-ecological systems', Ecological Modelling, Vol. 306, No. SI, pp.130-144.

Betzold, C. (2015) 'Adapting to climate change in small island developing states', Climatic Change, Vol. 133, pp.481-489.

Briguglio, L. (1995) 'Small island developing states and their economic vulnerabilities', World Development, Vol. 23, No. 9, pp.1615-1632.

Brito, A., Falcón, J.M. and Herrera, R. (2005) 'About the recent tropicalisation of the littoral ichthyofauna of the Canary Islands and its relationship with environmental changes and human activities', VIERAEA, Vol. 33, pp.515-525. 
Cunha, R., Rangel, B., Vieira, O. and Rego, I. (2010) 'Is it really happening here? A study of climate change perception in the Azores', WIT Transactions on Ecology and the Environment, Vol. 130, pp.113-120.

Fernandes, J., Guiomar, N. and Gil, A. (2015) 'Strategies for conservation planning and management of terrestrial ecosystems in small islands (exemplified for the Macaronesian islands)', Environmental Science \& Policy, Vol. 51, pp.1-22.

Fernández, J.I. and Cejas, F.R.R.M. (2009) 'Climate change and energy policy in the European Union's outermost regions: the case of the Canary Islands', Retfcerd Argang, Vol. 32, pp.41-60.

Gil, A. (2016) 'Thematic section: sustainable development and environmental conservation in the outermost European regions', Island Studies Journal, Vol. 11, No. 1, pp.5-8.

Gil, A., Fonseca, C. and Benedicto-Royuela, J. (2018) 'Land cover trade-offs in small oceanic islands: a temporal analysis of Pico Island, Azores', Land Degradation \& Development, Vol. 29, No. 2, pp.349-360.

Gil, A., Fonseca, C., Lobo, A. and Calado, H. (2012) 'Linking GMES space component to the development of land policies in outermost regions - the Azores (Portugal) case-study', European Journal of Remote Sensing, Vol. 45, No. 1, pp.263-281.

Grydehøj, A. and Kelman, I. (2017) 'The eco-island trap: climate change mitigation and conspicuous sustainability', Area, Vol. 49, No. 1, pp.106-113.

Hernández-González, Y., Guimarães-Pereira, Â., Rodríguez, S., Cuevas, E. and Barbosa, P. (2016) Perspectives on Contentions about Climate Change Adaptation in the Canary Islands: A Case Study for Tenerife, EUR 28340 EN Technical Report, Joint Research Centre, European Commission.

INE (2011) Censos 2011, Instituto Nacional de Estatística, Lisboa, Portugal.

IPCC (2018) Summary for Policymakers. An IPCC Special Report on the Impacts of Global Warming of $1.5^{\circ} \mathrm{C}$ above Pre-industrial Levels and related Global Greenhouse Gas Emission Pathways, in the Context of Strengthening the Global Response to the Threat of Climate Change, Sustainable Development, and Efforts to Eradicate Poverty, World Meteorological Organization, Geneva, Switzerland.

Kelman, I. (2010) 'Hearing local voices from small island developing states for climate change', Local Environment, Vol. 15, No. 7, pp.605-619.

Kelman, I. and Lewis, J. (2005) 'Ecology and vulnerability: islands and sustainable risk management', International Journal of Island Affairs, Vol. 14, No. 2, pp.4-12.

Kelman, I. and West, J.J. (2009) 'Climate change and small island developing states: a critical review', Ecological and Environmental Anthropology, Vol. 5, No. 1, pp.1-16.

Korsching, P.F. and Allen, J.C. (2004) 'Locality based entrepreneurship: a strategy for community economic vitality', Community Development Journal, Vol. 39, No. 4, pp.385-400.

Kubo, T., Tsuge, T., Abe, H. and Yamano, H. (2018) 'Understanding island residents' anxiety about impacts caused by climate change using Best-Worst Scaling: a case study of Amami islands, Japan', Sustainability Science, Vol. 14, pp.131-138.

Martínez, B., Afonso-Carrillo, J., Anadón, R., Araújo, R., Arenas, F., Arrontes, J., Bárbara, I., Borja, A., Díez, I., Duarte, L., Fernández, C., García Tasende, M., Gorostiaga, J.M., Juanes, J.A., Peteiro, C., Puente, A., Rico, J.M., Sangil, C., Sansón, M., Tuya, F. and Viejo, R.M. (2015) 'Regresión de las algas marinas en las Islas Canarias y en la costa atlántica de la Península Ibérica por efecto de cambio climático', ALGAS, Boletín Informativo de la Sociedad Española de Ficología, June, Vol. 49, pp.5-12.

McCright, A.M. (2010) 'The effects of gender on climate change knowledge and concern in the American public', Population and Environment, Vol. 32, No. 1, pp.66-87.

McNaught, R., Warrick, O. and Cooper, A. (2014) 'Communicating climate change for adaptation in rural communities: a Pacific study', Regional Environmental Change, Vol. 14, No. 4, pp.1491-1503. 
Melo, C.S., Ramalho, R.S., Quartau, R., Hipólito, A., Gil, A., Borges, P.A., Cardigos, F. et al. (2018) 'Genesis and morphological evolution of coastal talus-platforms (fajãs) with lagoons: the case study of the newly-formed Fajã dos Milagres (Corvo Island, Azores)', Geomorphology, Vol. 310, pp.138-152.

Mortreux, C. and Barnett, J. (2009) 'Climate change, migration and adaptation in Funafuti, Tuvalu', Global Environmental Change, Vol. 19, No. 1, pp.105-112.

National Research Council (2011) America's Climate Choices: Adapting to the Impacts of Climate Change, National Academies Press, Washington, DC.

Nunn, P.D., Runman, J., Falanruw, M. and Kumar, R. (2017) 'Culturally grounded responses to coastal change on islands in the Federated States of Micronesia, northwest Pacific Ocean', Regional Environmental Change, Vol. 17, No. 4, pp.959-971.

Nurse, L.A., McLean, R.F., Agard, J., Briguglio, L.P., Duvat-Magnan, V., Pelesikoti, N., Tompkins, E. and Webb, A. (2014) 'Small islands', Impacts, Adaptation, and Vulnerability. Part B: Regional Aspects. Contribution of Working Group II to the Fifth Assessment Report of the Intergovernmental Panel on Climate Change, pp.1613-1654, Cambridge University Press, Cambridge.

Pelling, M. and Uitto, J.I. (2001) 'Small island developing states: natural disaster vulnerability and global change', Global Environmental Change Part B: Environmental Hazards, Vol. 3, No. 2, pp.49-62.

Perkins, R.M. and Krause, S.M. (2018) 'Adapting to climate change impacts in Yap State, Federated States of Micronesia: the importance of environmental conditions and intangible cultural heritage', Island Studies Journal, Vol. 13, No. 1, pp.65-78.

Poortinga, W., Spence, A., Whitmarsh, L., Capstick, S. and Pidgeon, N.F. (2011) 'Uncertain climate: An investigation into public skepticism about anthropogenic climate change', Global Environmental Change, Vol. 21, No. 3, pp.1015-1024.

PRAC (2017) Programa Regional para as Alterações Climáticas, Açores, Portugal.

R Core Team (2017) R: A Language and Environment for Statistical Computing, R Foundation for Statistical Computing, Vienna, Austria.

Razzak, H. and Heumann, C. (2020) A Hybrid Technique for the Multiple Imputation of Survey Data, Technical Report 229, Department of Statistics, University of Munich.

SRAM (2004) Perspectivas para a sustentabilidade na Região Autónoma dos Açores, Secretaria Regional do Ambiente e do Mar, Açores, Portugal.

Stewart, J. (1995) 'A future for local authorities as community government', Local Government in the 1990s, pp.249-267, Springer, Palgrave, London.

Taherdoost, H. (2016) 'Validity and reliability of the research instrument; how to test the validation of a questionnaire/survey in a research', International Journal of Academic Research in Management, Vol. 5, No. 3, pp.28-36.

UNCFCC (1997) Kyoto Protocol to the United Nations Conference on Climate Change, UNFCCC, Kyoto, Japan.

Weir, T. and Pittock, J. (2017) 'Human dimensions of environmental change in small island developing states: some common themes', Regional Environmental Change, Vol. 17, No. 4, pp.949-958.

Weir, T., Dovey, L. and Orcherton, D. (2017) 'Social and cultural issues raised by climate change in Pacific Island countries: an overview', Regional Environmental Change, Vol. 17, No. 4, pp.1017-1028. 


\section{Supplementary material}

Assessing the local perception of climate change in a small island: a case study

Supplementary material: survey on climate change

1 Place of origin:

2 Education level:

3 Age:

4 Gender:

5 Profession (at least if it is linked to the environment):

6 Are you a member of an association linked to environmental conservation?:

$\square$ Yes

$\square$ No

7 Do you understand what climate change is?

$\square$ Yes

$\square$ No

If yes, can you give a short definition?:

8 Do you think that climate change really exists?

$\square$ Yes

$\square$ No

9 What do you think is the main reason for climate change?

$\square$ Natural origin

$\square$ Caused by humans and, mostly, agriculture and farming

$\square$ Caused by humans and, mostly, due to the reduction of forests

$\square$ Caused by humans and, mostly, by its economic activities and emissions

10 Do you believe that something can be done to prevent climate change?

$\square$ Yes

$\square$ No, it is too late

11 Actually, you think that climate change and its current impacts are for Corvo Island:

$\square$ The main problem

$\square$ An important problem 
$\square$ A secondary or reduced problem

$\square$ They are not a problem

12 Climate change will mostly affect:

$\square$ Humans

$\square$ Biodiversity

$\square$ Both

13 In the future, you think that climate change and its impacts will be for Corvo Island:

$\square$ The main problem

$\square$ An important problem

$\square$ A secondary or reduced problem

$\square$ They will not be a problem

14 Do you consider that some impacts will be positive for Corvo Island?

$\square$ Yes

$\square$ No

Which?:

Why?:

15 Do you think that strong rain and wind events in Corvo could affect local population?

$\square$ Yes

$\square$ No

How?:

What could be done to reduce these negative effects?:

16 Do you think that droughts could affect local population?

$\square$ Yes

$\square$ No

How?:

What could be done to reduce these negative effects?:

17 Could sea-level rise and coastal erosion affect local population?

$\square$ Yes

$\square$ No

How?: 
What could be done to reduce these negative effects?:

18 Could alteration in marine currents and sea water temperatures rise impacting local fish stocks affect local population?

$\square$ Yes

$\square$ No

How?:

What could be done to reduce these negative effects?:

19 Could the emergence of tropical diseases affect local population?

$\square$ Yes

$\square$ No

How?

What could be done to reduce these negative effects?:

20 Could the disappearance or displacement of local flora and fauna species affect local population?

$\square$ Yes

$\square$ No

How?:

What could be done to reduce these negative effects?:

21 Do you think that the regional government is preparing the region to climate change?

$\square$ Yes

$\square$ Yes, but it is not enough

$\square$ No

22 Have you heard about the PRAC - Regional Plan for Climate Change?

$\square$ Yes

$\square$ No

If yes, can you give a short definition with your own words?:

23 Do you think that local government must take advice from local population to find solutions in the fights against climate change?

$\square$ Yes

$\square$ No 
24 Could you, at your personal level, be doing something to reduce climate change?

$\square$ Yes

$\square$ No

What?

25 Do you think that Corvo Island community can do something to reduce climate change?

$\square$ Yes

$\square$ No

What?

26 Which places do you identified as being most vulnerable to climate change? 